\title{
Christian Religious Education Management, Government Service, in Cell Groups on The Quality of the Faith of Church Members
}

\author{
Imron Widjaja \\ Periago Theological Seminary, Jakarta, Indonesia \\ imron.widjaja@gmail.com \\ Lasmaria Nami Simanungkalit \\ Moriah Theological Seminary, Tangerang, Indonesia \\ namilasmaria@yahoo.com
}

\begin{abstract}
This study examines the management of christian religious education as one form of shepherding service formation in cell groups in maturing, guiding and directing to apply the word of God. Christian religious education management as a model and example in the formation of church pastors in reaching sinners for Christ. This research was conducted at GBI Graha Pena with a total sample of 88 people who were active in participating in cell groups. The results of this study indicate that educational services are good that have led to pastoral care in realizing the Quality of Faith of GBI Graha Pena congregation members to reach people who do not yet believe in Christ. The effectiveness of the implementation of pastoral services that lead to the tasks and objectives of the church's mission through cell groups seen from members of cell groups who see the effectiveness of the service is supported by effectiveness: 58 respondents visitation (65.9\%), help of sick people 88 respondents (100\%), prayer of release 88 respondents (100\%), service grief 88 respondents (100\%).
\end{abstract}

\section{Article History:}

Received 2 May 2020

Accepted 15 July 2020

Keywords:

christian religious education, pastoral services, cell groups, quality of faith

\section{Introduction}

Christian Religious Management, Pastoral Services, Cell Group on the Quality of Faith Members of the GBI Graha Pena Church that the biblical purpose of God s to build His church as individuals who are reflected in the sermon of the Lord Jesus on the mount. ${ }^{1}$ The sermon of the Lord Jesus on the mount was intended by God to build His church as individuals and seek the personalities of the citizens of God's kingdom. The author believes that in connection with these teachings, the ministry of pastoral care of the quality of the faith of members of the GBI Graha Pena congregation is very important. The Lord Jesus taught, also gave guidance by

\footnotetext{
${ }^{1}$ Matthew 5:48; Luke 6:20-23
} 
preaching and Christian Religious Education (CRE) pastoral care carried out in cell groups on the quality of faith of members of the congregation GBI Graha Pena.

Steps taken in the CRE, Pastoral Service, Cell Groups for the Quality of Faith of GBI Graha Pena Members, the sermon is a painting given by the Lord Jesus that His followers need to do. The Sermon on the Mount reveals two words that expose challenges to the modern world, that is the expression of counter-culture and alternative culture. ${ }^{2}$ The sermon teaches about the kingdom of God which has long been promised in the Old Testament. The Lord Jesus Himself has come to begin His ministry. With Him the dawn of the new century has broken, and God's government has broken through history. "Repent, "the Lord Jesus exclaimed, because the kingdom of heaven is at hand. ${ }^{3}$ Since then the Lord Jesus began to carry out His shepherding ministry. He traveled all over Galilee, he taught in synagogues and preached the gospel of the kingdom of God. ${ }^{4}$ The Sermon on the Mount depicts CRE, the Pastoral Service, Cell Groups for the Quality of Faith Members of the GBI Graha Pena Church preach the way of repentance (Metanoia, total change of heart and mind) and the truth which are elements of the kingdom.

In the view of the key writers of the Sermon on the Mount is: "Do not be like them." This command of God teaches the changing attitudes of people who already believed in the Lord Jesus as Lord and Savior. The author here considers the importance of education, pastoral care carried out in cell groups will enhance and advance and grow and mature the quality of faith of members of the congregation who follow cell groups held by GBI Graha Pena in various regions. Observation at GBI Graha Pena shows that there is an effort to develop CRE, pastoral services, cell groups through an approach with "PRT or komsel" (Household Fellowship or Cell Community). The cell groups are church services to improve pastoral care that leads to the mission tasks and objectives of the church to church members. It was done because pastoral care that leads to the task and purpose of the church's mission is one part of the church's service to

${ }^{2}$ John R. W. Stott, The Message of the Semon on the Mount (Leicester: Inter Varsity Press 1989), 1 (Direct translation). For further, The books of foreign languages in the writing of this dissertation are directly translated by the author. Comp Andra Diana Coman, et. al, Communication and Group Cognitive Complexity, Journal of Small Group Research, Vol.50, Iss.4 (2019): 539-568. DOI: 10.1177/1046496419853624.

${ }_{3}^{3}$ Mattthew 4:17

${ }^{4}$ Matthew 6:8

${ }^{5}$ Matthew 6:8 
pay attention, provide direction or a way out for members of the church who worship in the church. ${ }^{6}$

Christian religious education management, pastoral service, group for the quality of faith in members of the congregation of GBI (Indonesian Bethel Church) by address in Graha is one of the most important and basic services for God's church on earth. God Himself is described as "the Great Shepherd and the Good Shepherd."” Jesus said: "I am the good Shepherd. The good shepherd gives his life for his sheep." In this connection, the pastoral service that leads to the task and purpose of the church's mission is one example set by the Lord for us, so that we emulate Him and follow Him. ${ }^{9}$

\section{Formulation of the problem}

The problems in this study are formulated as follows: 1. How CRE, pastoral care services, cell groups on the quality of faith members of the congregation GBI Graha Pena in komselkomsel should be directed more towards good management. Cell groups in general is implemented by large churches in the cities so it needs to be managed by education management. 2. The effectiveness of the application of pastoral ministers that lead the task and purpose of the church's mission through cell groups. 3. What is the level of effectiveness of pastoral service that leads to the tasks and objectives of the cell group church's mission compared to service in the mother church.

\section{Theoritical Review}

The Apostle Paul stated: " . He is the one who gives both the apostles and the prophets, both the evangelists and the pastors and teachers." ${ }^{10}$ This passage convinces that the Lord set up

${ }^{6}$ Church services include: visitation services, counseling services, released prayer services, mourning services, mentoring services for the sick, mentoring services for people affected by drugs, water baptism services, and marriage services. Comp. Andra Diana Coman, et. al, Communication and Group Cognitive Complexity: 539568.

${ }^{7}$ Psalm 23:1-6; EZEkiel 34; John 10:1-21; Mattthew 28:19-20

${ }^{8}$ John $10-11$

${ }^{9}$ Bill Donahue, Charles Gowler, Small Groups: The Same Yesterday, Today, and Forever?, Christian Education Journal: Research on Educational Ministry, Vol.11, Iss.1, (2014): 118-133. DOI: 10.1177/073989131401100110.

${ }^{10}$ Ephesian 4:11 
a pastoral ministry who leads to the mission tasks and objectives of the church. Thus the shepherd is responsible to God and to others. ${ }^{11}$

Leon Moris explained in the call of love to God (agape love). Agape love for God became the basis of the vocation, then followed by the herding mandate. uch a call sparked love for the sheep. That love is based on the love of Christ as a good Shepherd to His sheep, those who are saved by His sacrifice. This was stated by Leon Moris as follows:

There can be little doubt but that the whole scene is meant to show us Peter as completely restored to his position of leadership. He has three times denied his Lord. Now he has three time a affirmed his love for him, and three times he has been commissioned to care for the flock. This must have had the effect on the others of a demonstration that, whatever had been the mistakes of the past, Jesus was restoring Peter to a place of trust. It is further worth noting that the one thing about which Jesus questions Peter prior to commissioning him to tend the flock is love. This is the basic qualification for Christian service. Other qualities may be desirable but love completely indispensable (1 Cor. 13:1-3). ${ }^{12}$

Sceward Hiltner states that theologically identifies shepherding as a branch or field of knowledge and theological inquiry that directs the shepherding perspective to all the tasks, obligations and functions of the church and shepherds in theological form of reflection on these observations. ${ }^{13}$ The term is supported by a number of God's words which are essentially started and ended by God himself. God Himself is the Shepherd of the people of Israel according to Psalm 80: 1, which shows the meaning of His love as the Great Shepherd who gave His life for the sheep. We will study this theology of shepherding from the shepherding pattern of the Old and New Testaments. Robert C. Anderson defines shepherding as the duty of God's servants in evangelizing people, completing it, caring for it, leading it, teaching it to do God's will. ${ }^{14}$ The opinion expressed by Anderson, that the task of the servant of God is not only as a shepherd but contains the understanding as an evangelist and someone who coordinates a work.

\footnotetext{
${ }^{11}$ Matthews 5:13-16.

11 Leon Morris, The Gospel According to John, the English Text with Introduction, Exposition and Notes (Grand Rapids: William B. Eerdmans Publishing Company, 1999), 875.

25.

${ }^{13}$ Sceward Hilter, as quoted by Derek J. Tidball, Teologia Pengembalaan, (Malang: Gandum Mas, 1995),

14 Robert C. Anderson, The Effective Pastor, (Chicago: Moody Bible Institute, 1993), 158. See Andra Diana Coman, et. al, Communication and Group Cognitive Complexity: 539-568.
} 
Thureysen said: "Shepherding is a special application of the gospel to members of the congregation in person, that is the message of the gospel in the church sermon, delivered to everyone. ${ }^{\prime 15}$ Pastoral care implements a work that the Lord Jesus once did in this world in shepherding and evangelism. This is contained in the Gospels, and this message must be conveyed to everyone and church members for them to prepare to witness the witness of Christ. $^{16}$

H. Faber said: "shepherding is every work in which the servant is aware of the consequences of his conversation or preaching on the personality of the person he is contacting. ${ }^{17}$ In this case Feber does not merely emphasize what is said by the minister (pastor, elder, etc.), but how the servant's attention is received by members of the congregation and how it influences personality, those were the thoughts, feelings and acknowledgment of members of the congregation. Comparison of the three definitions above, referring to both eyes, which are exegeseally explained in the previous pages All three emphasize the ministry of pastoral care that leads to the task and purpose of the church's mission in the relationship between pastors, ministers and members of the congregation. ${ }^{18}$

J. W. Herfst writes that the task of shepherding is to help people individually to realize their relationship with God, and to teach people to acknowledge obedience to God and others, in their own situation. ${ }^{19}$ The ministry of pastoral care that leads to the task and purpose of the church's mission can be referred to as follows: First, the pastoral ministry to the congregation. Second, the pastoral ministry builds congregations to worship. Third, the pastoral ministry is looking for heretics. Fourth, the pastoral ministry is preaching the Word. Fifth, the pastoral service in advising and reprimanding. The Lord Jesus gave the message to the apostle Peter to feed His sheeps. He likens and syncronizes service to the brothers in Christ as shepherding. So our brothers and sisters in Christ must be guarded, satisfied, cared for and saved from danger. The word shepherd in Greek is poimen. In Latin, it is called a priest. Therefore shepherding in the church can be called poimenika or pastoralia. Pastoral care is pastoral sheperding. Pastoral care in the church can be formulated as follows:

\footnotetext{
${ }^{15}$ Robert C. Anderson, The Effective Pastor, 12.

${ }^{16}$ See Bill Donahue, Charles Gowler, Small Groups: The Same Yesterday, Today, and Forever?: 118-133.

${ }^{17}$ Robert C. Anderson, The Effective Pastor, 15.

${ }_{18}^{18}$ M. Bons-Strom, Apakah Pengembalaan itu? (Jakarta: BPK Gunung Mulia, 1993), 20.

${ }^{19}$ J. W. Herfst, as quoted by Bons-Strom, Apakah Pengembalaan itu? 19.
} 
First, search, visit and contact church members one by one. Second, preach the word of God to them in their personal life situation. Third, serve them as Jesus served them. Fourth, reprimand and discipline those who deviate and the right path. Fifth, teach them by example with words so that they do God's will in daily life. Sixth, help them witness the message of salvation in the Lord Jesus Christ. Seventh, equipping them with the ability and skills to serve, to be mature, apologist and build the body of Christ. ${ }^{20}$

The principle of the Cell Church in general is the church which makes the cell everything in which all activities are modified in the form of cells. Example: Sunday school is diverted into child cell groups, youth services are made into youth, youth, student cell groups etc.. Likewise, female cell groups, male cell groups, professional cell groups, family cell groups, etc. are formed. The smaller the number of people in each group, the growth of faith of each member is more easily addressed. Cell group strategy does not reject the existence of large activities, but all activities are aimed at strengthening the service of cell groups. ${ }^{21}$ In connectionwith this matter, Lowrence Khong, pastor of the Baptist Church in Singapore said, "There is a big difference between churches that have cells and cell churches. We do nothing else, except cells. Everything the church does - training, completing, discipleship, evangelism, prayer, worship is done through cells. Our Sunday services are only corporate worship services. ${ }^{22}$

GBI located at Graha Pena, which is part of the large family of the Indonesian Bethel Church, also applies the principle of church duties in general as mentioned above. But in its local strategy add to a principle called pastoralia (quoting the wisdom of the pastor of the GBI location at Graha Pena).

In principle, cell groups in GBI located at Graha Pena are not run purely. The author calls the system with the name "cell group" (note: this name is not yet commonly used because so far it has not been given a name).

Understanding the principle of cell groups is organizing cell groups as one part of church activities and is not the only system implemented in the church as practiced by cell churches, are similarities and differences between cell churches and cell groups, Sunday worship in cell group patterns, patterns leadership in cell churches, leadership patterns in cell groups.

\footnotetext{
${ }^{20}$ Herfst, Apakah Penggembalaan itu?, 23.

${ }^{21}$ See Bill Donahue, Charles Gowler, Small Groups: The Same Yesterday, Today, and Forever?: 118-133.

${ }^{22}$ Joel Comiskey, Ledakan Kelompok Sel, (Jakarta: Yayasan Buana Indonesia, 1998), 17.
} 
First, the similarities and differences between cell churches and cell groups. The similarities are: Equally oriented towards service to the congregation: teaching, worship services, and so on (more general). Other similarities are: Equally oriented to the needs of the congregation, for example: Diaconia service, counseling service, etc. (more specific).

Second, there are some differences between cell churches and semi-cell groups. First, in the cell church, cell activity is primary, and all other activities are supporting the successful growth of each cell. In cell groups, cells are only one of all activities, sometimes even a variety of methods. Second, Sunday worship in the cell church pattern is a side effect (in the sense that it is not the only one). It is said so, because after there is worship in cell meetings, and each member has been guided to accept Christ to become a true worshiper. Therefore, Sunday service is a continuation that enriches the worship life of members. In semi-cell groups, Sunday service is the main activity, and it is possible that many people who come to church have not had a right relationship with Christ, have not repented and have not yet clear as true worshipers in spirit and truth. This is an obstacle to the growth of the Church, so many of the church members who have not been converted and born again by the Holy Spirit. ${ }^{23}$

Third, the leadership pattern in cell church is a pattern of plural leadership, where everyone has the opportunity to be empowered to become a leader through continuous training. In the cell group pattern, the leadership pattern is single leadership, one person needs everything. Fourth, in the cell church, the cell is an outreach system. Everyone not only learns for himself, but also learns how to reach out to others outside his group with the gospel message, so that other people can come and believe in Jesus. ${ }^{24}$

\section{Methods}

\section{Place and Time of Research}

This research was conducted at the Indonesian Bethel Church in Graha Pena, South Jakarta. The time of this research is in 2019.

\footnotetext{
${ }^{23}$ William Sawyer, Christian Spirituality and Small Group Effectiveness: A Socio-rhetorical Analysis of Acts 6:1-7, Emerging Leadership Journeys, Vol.8, Iss.1 (2015): 5-13.

${ }^{24}$ William Sawyer, Christian Spirituality and Small Group Effectiveness: A Socio-rhetorical Analysis of Acts 6:1-7: 4, 7, 9, 12 .
} 


\section{Research Methods}

This research used quantitative research. ${ }^{25}$ The first step, data collection is obtained through research. The second step, grazing data is collected through the study of the Petamburan GBI Cell Group documents, such as the visit of members participating in cell groups. The third step, get data from cell church seminar paper papers in $1998 .^{26}$ And data obtained from collection of cell church seminars held at the GBI Keluarga Allah (Family of God). ${ }^{27}$ The fourth step, the data obtained from a questionnaire distributed to eighty-eight members of the Cell Group, the questionnaire format was compiled by the author himself based on his own needs. Data testing was carried out with SPSS (Statistic Package For Social Science). The fifth step, interviews, structurally carried out interview data needed for the purpose of the GBI Petamburan pilgrimage.

\section{Population and Sample}

The population of this research is the whole congregation that is incorporated and active in the group activities at the Indonesian Bethel Church in Graha Pena, South Jakarta. The number of samples in this study were 88 people. The sampling technique is done by purposive sampling, is the selection of samples based on the goals that have been set, ie only for congregations involved in cell groups.

\section{Discussion and Result}

From the results of the frequency test on how you feel that pastoral service is conducted in komsel from 88 respondents obtained as follows: as many as 1 person or 1.1\% who did not give answers, as many as 75 people or $85.2 \%$ who stated good and as many as 12 people or $13.6 \%$ stated very well.

${ }^{25}$ See John W. Creswell; J. David Creswell, Research Design: Qualitative, Quantitative, and Mixed Methods Approaches, (Thousand Oaks, California: SAGE Publications, 2014), 206-258; Geoffrey R. Marczyk, David DeMatteo, David Festinger, Essentials of Research Design and Methodology, (Hoboken, New Jersey: John Wiley \& Sons, 2005), 123-157.

${ }^{26}$ The seminar was held at wisma Kinasih, Jawa Barat, 18-21

${ }^{27}$ The seminar was held at Solo, Jawa Tengah, 12-15 Oktober 1999. 
Table 5.1. How would you rate the pastoral care service in Cell Groups?

\begin{tabular}{|c|c|c|c|c|c|}
\hline & & Frequency & Percent & Valid Percent & Cumulative Percent \\
\hline & 0 & 1 & 1.1 & 1.1 & 1.1 \\
\hline & Good & 75 & 85.2 & 85.2 & 86.4 \\
\hline & Very Good & 12 & 13.6 & 13.6 & 100.0 \\
\hline & Total & 88 & 100.0 & 100.0 & \\
\hline
\end{tabular}

From the results of the frequency test on how you are willing to support if grazing services are carried out in cell group out of 88 respondents obtained as follows: as many as 1 person or $1.1 \%$ who did not answer, as many as 66 people or $75.0 \%$ who said they supported and as many as 21 people or $23.9 \%$ who said they were very supportive.

Tabel 5.2 How would you be willing to support a pastoral ministry done in cell group

\begin{tabular}{||l|l||r||r||r||r||}
\hline \multicolumn{1}{|c|}{} & Frequency & Percent & Valid Percent & Cumulative Percent \\
\hline \hline \multirow{4}{*}{ Valid } & 0 & 1 & 1.1 & 1.1 & 1.1 \\
\cline { 2 - 7 } & Supportive & 66 & 75.0 & 75.0 & 76.1 \\
\cline { 2 - 6 } & Very Supportive & 21 & 23.9 & 23.9 & 100.0 \\
\cline { 2 - 6 } & Total & 88 & 100.0 & 100.0 & \\
\hline \hline
\end{tabular}

From the results of the frequency test about whether there is a profit if the grazing service is carried out in the Cell Group of 88 respondents obtained as follows: as many as 1 person or $1.1 \%$ who did not give an answer, as many as 66 people or $75.0 \%$ who stated there were profits and as many as 21 people or $23.9 \%$ who declared very profitable. 
Tabel 5.3. Are there advantages if pastoral care is done in cell group

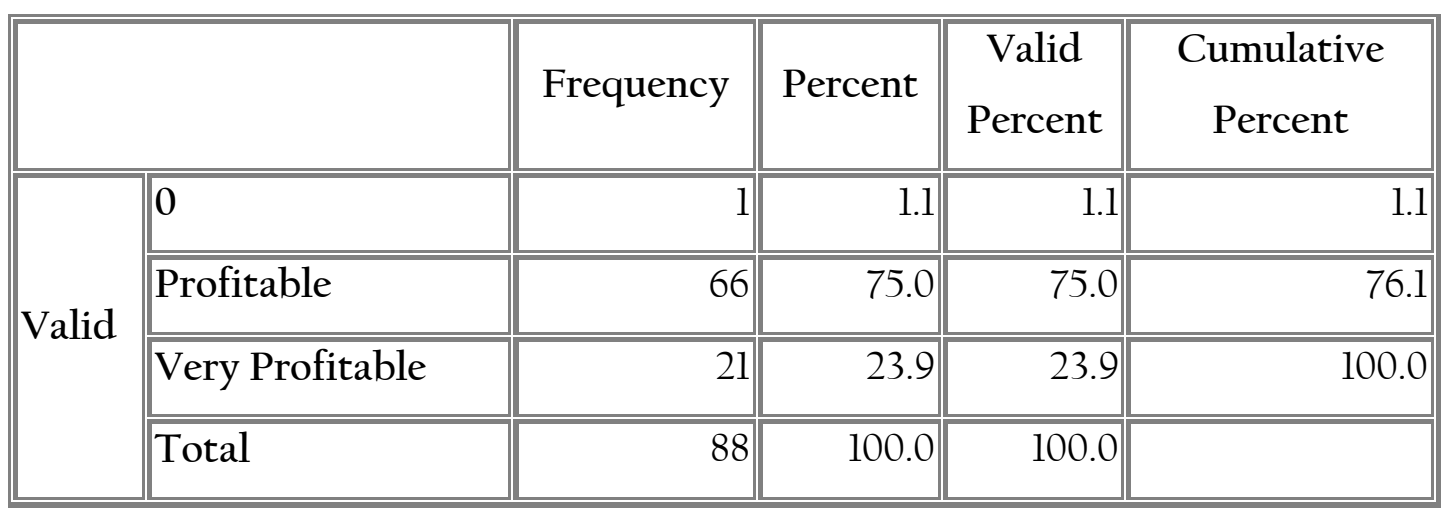

From the results of the frequency test about whether you want the pastoral service to be conducted in the Cell Group of 88 respondents obtained as follows as many as 1 person or 1.1\% who did not provide an answer, as many as 87 people or $98.9 \%$ who said they wanted.

Tabel 5.4. Do you want the pastoral service to be carried out in the cell group

\begin{tabular}{|c|c|c|c|c|c|}
\hline & & Frequency & Percent & Valid Percent & Cumulative Percent \\
\hline \multirow{3}{*}{ Valid } & 0 & 1 & 1.1 & 1.1 & 1.1 \\
\hline & Wanted & 87 & 98.9 & 98.9 & 100.0 \\
\hline & Total & 88 & 100.0 & 100.0 & \\
\hline
\end{tabular}

From the results of the frequency test of how the congregation is doing if the pastoral service is conducted in Cell Group from 88 respondents obtained as follows: as many as 1 person or $1.1 \%$ who did not give an answer, as many as 87 people or $98.9 \%$ who claimed to get attention.

Tabel 5.5. What is the condition of the congregation if the pastoral service is carried out in the cell group

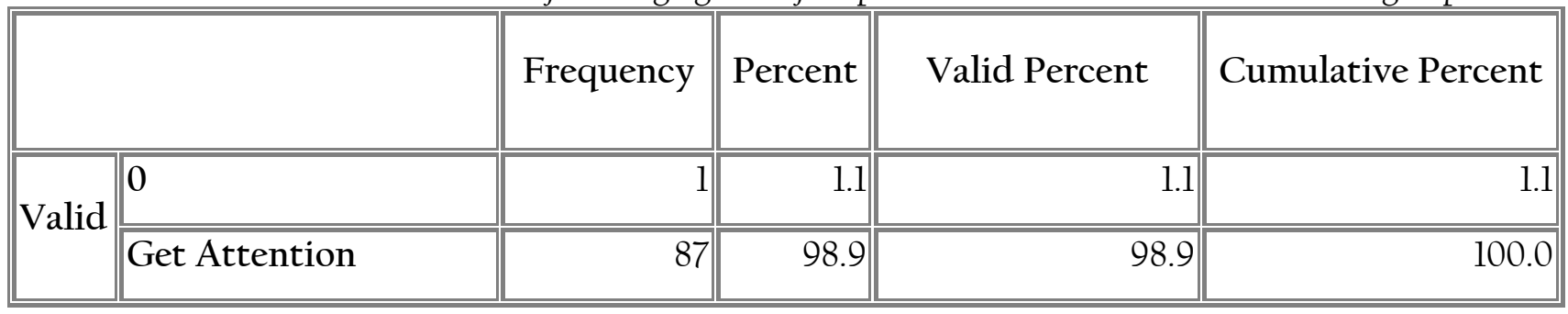




\begin{tabular}{|c|c|c|}
\hline Total & 88 & 100.0 \\
\hline
\end{tabular}

From the results of the frequency test about whether your opinion if the pastoral care service in Cell Group has added new souls from 88 respondents obtained as follows: as many as 1 person or $1.1 \%$ who did not give an answer, as many as 87 people or $98.9 \%$ who said there were additional lives new.

Tabel 5.6. What is your opinion if the pastoral service in South Sumatra has an addition of new congregation

\begin{tabular}{|c|c|c|c|c|c|}
\hline & & Frequency & Percent & Valid Percent & Cumulative Percent \\
\hline \multirow{3}{*}{ Valid } & 0 & 1 & 1.1 & 1.1 & 1.1 \\
\hline & In addition & 87 & 98.9 & 98.9 & 100.0 \\
\hline & Total & 88 & 100.0 & 100.0 & \\
\hline
\end{tabular}

Analysis of the available facts are divided into three stages, that were: first, analysis of the advantages, second, the lack of cell group systems, and thirdly the effectiveness of the application of pastoral care that leads to the tasks and objectives of the church's mission through cell group.

First, the advantages of educational management in the application of pastoral care that lead to the tasks and objectives of the church's mission through cell groups is first to facilitate outreach to church members so that church members can be better served. This is supported by the data in the results of the study: 88 respondents (100\%) stated that they had: visited, counseled, received deliverance prayer, received sorrow services, assisted the sick, assisted drug victims, 87 respondents (98.9\%) supported the implementation of herding services which leads to the tasks and objectives of the church's mission through cell group, location of the cell group residence with the house of the congregation 86 respondents (97.7\%) close together; Giving an opportunity to church members to be able to develop their spiritual gifts is the second advantage of applying pastoral care that leads to the task and purpose of the church's mission through cell groups. This is supported by the data in the results of the study: the chairman formed the service team: visitation of 87 respondents (98.9\%), counseling 67 respondents 
(76.1\%), helping sick members of the community, release prayer, the grief of 88 respondents (100\%), encouragement of the chair of the cell group and team to community members to be involved in pastoral care that leads to the task and mission objectives of the church 88 respondents (100\%), invite members of the community to visit 88 respondents $(100 \%)$. Third, Cell group members will be more intimate, able to care for one another and serve one another; supported by research data: Cell group members reported their situation to the chairman of 47 respondents (53.4\%), Cell group members subordinated the souls of 47 respondents (53.4\%), satisfaction of Cell Group to the service of the leader of the Cell group and the team 86 respondents (97.7\%), introduction among the Cell Group members 77 respondents (87.5\%), a sense of unity among fellow members of the community.

Second, the effectiveness of education management in the implementation of pastoral care services that lead to the tasks and objectives of the church's mission through cell groups seen from members of Cell group who see the effectiveness of the service is supported by effectiveness: visitation of 58 respondents (65.9\%), help of sick people 88 respondents (100\%), prayer for the release of 88 respondents (100\%), grief service 88 respondents $(100 \%)$. This can lighten the task of implementing pastoral services that lead to the tasks and objectives of the church's mission carried out by the Pastor of Church Congregation.

Third, the analysis of weaknesses in the application of pastoral care if not carried out in an educational management that leads to the tasks and objectives of the church's mission through cell group that can not be done is marriage service, data shows 88 respondents (100\%) have never done in cell group; water baptism services, data shows 88 respondents (100\%) have never done in cell group. These two things are not done in cell groups because if done by the church in the church, it will cause church division.

Fourth, the effectiveness of the implementation of pastoral services that lead to the tasks and objectives of the church's mission through cell groups seen from members of cell groups who see the effectiveness of the service is supported by effectiveness: 58 respondents visitation (65.9\%), help of sick people 88 respondents (100\%), prayer of release 88 respondents (100\%), service grief 88 respondents (100\%). This can lighten the task of implementing pastoral services that lead to the tasks and objectives of the church's mission carried out by the Pastor of Church Congregation. 


\section{Conclusion}

Based on the results of the analysis, it shows that cell group service is very important and the church should carry out in fostering the spiritual life of the congregation. So Educational Management plays an important role in cell groups that are very desirable and needed by the congregation. Through educational management in cell groups, the church gets good pastoral care, where it gets the attention of the church. By conducting and implementing educational management, cell group services have an impact on changes in the life of the congregation. The results of the analysis also show that through cell groups, church membership is gained or increased. Where cell groups are an effective method of reaching new souls or sinners to be guided and receive the gift of salvation in Jesus Christ.

The church should apply cell group services well. The service methods are creatively designed and in accordance with the needs of the congregation. The cell group leader should carry out the pastoral service function by giving the members proper attention. Every cell group member should also be given training in soul outreach so that this service can develop as expected.

\section{Bibliography}

Alkitab. Jakarta: Lembaga Alkitab Indonesia, 1995.

Anderson, Robert C.The Effective Pastor. Chicago: Moody Institute, 1993.

Baker, Steve F.Tal. Buku Pegangan Pemimpin Kelompok Kecil. Diterjemahkan Oleh Agus B. Lay. Jakarta: Perkantas, 1995.

Barclay, Wiliam. The Letters to Timothy, Titus and Filemon. Philadelphia: West Minster Press, 1956.

Bernard, H. Russel. Research Methods in Cultural Anthropology. Newbury Park: Sage Publication Inc, 1990.

Brink, H. Van den. Tafsiran Kisah Rasul. Diterjemahkan Oleh J. Widya Kartono. Jakarta: BPK Gunung Mulia,1960.

Bruce, F.F. Paul Apostle Of the free Spirit. Leicester: The Paternoster Press,1977.

Budiman, R. Surat-surat Pastoral I \& II Timotius dan Titus. Jakarta: BPK Gunung Mulia, 1992.

Chadwick, W.E. Pastoral Teaching of Paul. Grand Rapids, Grand Rapid: Kregel Publication, 1984. 
Clemens, John K. Steve Albrecht. The Timeless Leader ( Pemimpin Sepanjang Masa), Jakarta: Professional Books, 1997.

Coman, Andra Diana; et. al. Communication and Group Cognitive Complexity, Journal of Small Group Research, Vol.50, Iss.4 (2019): 539-568. DOI: 10.1177/1046496419853624.

Cornelius, Helena dan Faire Shoshana. Siapa Pun Bisa Menang. Jakarta: Gramedia Pustaka Utama, 1995.

Creswell, John W.; Creswell, J. David. Research Design: Qualitative, Quantitative, and Mixed Methods Approaches, Thousand Oaks, California: SAGE Publications, 2014.

Dayton, Edward R. dan David A. Fraser . Planning Strategies for Word Evangelization. Grand Rapid: William B. Eerdmans Publishing Company,1980.

Dinnen, Stewart. You Can Learn to Learn to Lead. Ross-Shire: The Buernsey Press Co. Ltd, 1998.

Donahue, Bill; Gowler, Charles. Small Groups: The Same Yesterday, Today, and Forever?. Christian Education Journal: Research on Educational Ministry, Vol.11, Iss.1, (2014): 118-133. DOI: 10.1177/073989131401100110.

Elliot, W. Winston. Church Growth Leadership. Singapore: Abundant Press,1993.

Erwin, Gayle D. The Jesus Style. West Covina: Servant Quarters, 1993.

Fee, Gordon D. New International Biblical Commentary 1 and 2 Timothy, Titus. Carlisle: The Paternoster Press, 1995.

Gibbs, Eddiee. I Believe In Church Growth. Grand Rapids: William B. Eerdmans Publishing Company, 1981.

Gordon, Thomas. Menjadi Pemimpin Efektif. Jakarta: Gramedia Pustaka Utama, 1997.

Graham, Stedman. You Can Make it Happen. New York: Fireside Roekefeller Center, 1997.

Gundry, Robert H. A Survey of The New Testament. Grand Rapid: Zondervan Publishing House, 1981.

Haggai, John Edmund. The Leading Edge. Dallas: Word Publishing, 1988. .The Steward.Nashville, Tennessee: The Parthernon Press,1983. .Be Careful What You Call Imposible, Altanta: Kaabrey Press, 1989. .Lead on. Singapore: BAC Printers, 1986.

Hammond, Jeff. Akhir Zaman: Sudah Tiba. Jakarta: Metanoia, 1998.

Hartono, Chris. Peranan Organisasi Gereja. Jakarta: BPK Guung Mulia, 1978. 
Hasselgrove, David J dan Romsnen Edward .Kontekstualisasi. Jakarta: BPK Gunung Mulia, 1995.

Henrichson, Walter A \& William H. Garrison. Lay Man, Look Up! God has a Place For You. Grand Rapids: Zondervan Publishing House, 1983.

Hickman, H.C dan M.A.Silva. Creating Excellence: Managing Coorprate Culture, Strategy and Change in the New Age. New York: New American Library, 1984.

Maxweel, John C. 17 Buku Hukum Kerja Sama. Batam: Interaksara, 2002.

Marczyk, Geoffrey R.; DeMatteo, David; Festinger, David. Essentials of Research Design and Methodology, Hoboken, New Jersey: John Wiley \& Sons, 2005.

Sawyer, William. Christian Spirituality and Small Group Effectiveness: A Socio-rhetorical Analysis of Acts 6:1-7. Emerging Leadership Journeys. Vol.8, Iss.1 (2015): 1-21.

Senduk, H.L. Hanya Oleh Anugerah. Jakarta: Varia Warna Wacanajaya, 1999.

Setiawan Tanto, Obaja. Prinsip 12: Rahasia Pertumbuhan Gereja. Solo: Departemen Media Keluarga Allah, 2000.

Stockstill, Larry. Gereja Sel: Mempersiapkan Gereja Menghadapi Masa Penuaian. Jakarta: Metanoia, 2000.

Stott, John. Khotbah Di Bukit. Jakarta: Yayasan Komunikasi Bina Kasih/OMF, 1999.

Warren, Rick. The Purpose Driven Church. Grand Rapids: Zondervan Publishing House, 1995.

Wongso, Peter. Pelayanan Seorang Hamba. Malang: SAAT, 1992.

Yoder . Lawrence M Tunas Kecil. Semarang: Komisi Literatur Sinode GKMI, 1980.

Zuck, Roy B. Vital Ministry Issues. Grand Rapids: Kregel Resources, 1994. 